\title{
Assessment of thermal performance of heat pipe by using nanofluid
}

\author{
S. M. Sakhare Chougule* and S. H. Sarje \\ JSPM's Imperial College of Engineering \& Research, Wagholi, Pune-14, India \\ Accepted 15 June 2016, Available online 20 June 2016, Special Issue-5 (June 2016)
}

\begin{abstract}
The experimental set up has prepared to study effect of nanofluid on the thermal performance of the heat pipe. The circular section heat pipe, temperature sensor, heater and control panel have used in the experimental set up. The control panel includes temperature indicator, voltmeter, ammeter and dimmerstat. The nanofluid is water based $\mathrm{Al}_{2} \mathrm{O}_{3}$ with three concentrations $0.1 \%, 0.3 \%$ and $0.5 \%$. The thermal performance of heat pipe has tested for different heat inputs and concentrations of $\mathrm{Al}_{2} \mathrm{O}_{3}$. The observations were taken by passing both pure water and three concentrations of $\mathrm{Al}_{2} \mathrm{O}_{3}$ over the condenser section of heat pipe. The heat transfer rate has increased in condenser section of heat pipe when nanofluid was passed and it has lowered when pure water is passed. For $0.1 \%$ and $0.3 \%$ concentration of $\mathrm{Al}_{2} \mathrm{O}_{3}$, heat transfer has increased and for $0.5 \%$ concentration it has lowered to some extent but more than pure water. For $0.3 \%$ concentration of $\mathrm{Al}_{2} \mathrm{O}_{3}$ maximum heat transfer has observed. Also the condenser wall temperature of the heat pipe has decreases when nanofluid was passed.
\end{abstract}

Keywords: Heat pipe, $\mathrm{Al}_{2} \mathrm{O}_{3}$, nanofluid, heat transfer, thermal performance, concentrations.

\section{Introduction}

The new method for increasing the thermal performance of the heat pipe is to use working fluid as a nanofluid. Nanofluids has new class of fluids produced by dispersing nanometer sized particles in the base fluid. Nanofluids have two phase system solid phase and liquid phase. It have been found that nanofluid possess excellent thermo physical properties like thermal diffusivity, convective heat transfer and thermal conductivity as compared to base fluid such as water or oil. Water, ethylene glycol and engine oil are the traditional base fluids used in heat pipe for heat transfer. The mixture of base fluid and nano particles is termed as nanofluids. Nanoparticles may be pure metals ( $\mathrm{Al}, \mathrm{Ag}, \mathrm{Cu}$, and $\mathrm{Fe}$ ), metal oxides ( $\mathrm{CuO}, \mathrm{SiO} 2$, $\mathrm{Al}_{2} \mathrm{O}_{3}, \mathrm{TiO}_{2}, \mathrm{ZnO}$, and $\mathrm{Fe}_{3} \mathrm{O}_{4}$ ), Carbides ( $\mathrm{SiC}, \mathrm{TiC}$ ), Nitrides (AlN, SiN) and different types of carbon (diamond, graphite, single/multi wall carbon nanotubes). The heat pipe is special type of heat exchanger. The heat can effectively transfer with the help of heat pipe in which the nanofluid flows into evaporator and condenser section of heat pipe. The heat pipe found its applications in various fields such as aerospace applications, heat transfer systems, cooling of computers, cell phones and cooling of solar collector. Also nanofluid found its applications in industrial cooling, heating buildings, nuclear system cooling, space and defense, biomedical applications etc.

*Corresponding author: S. M. Sakhare Chougule

\section{Literature Review}

Paisarn Naphon investigated thermal efficiency of heat pipe with titanium nanofluid. $21 \mathrm{~nm}$ diameter titanium nanoparticle with mixture of alcohol was used and nanofluid were prepared by ultrasonic homogenizer. He studied effects of heat pipe tilt angle, percentage charge amount of working fluid and different volume concentrations of nanofluid on thermal efficiency. He found that heat pipe efficiency increases with tilt angle up to $60^{\circ}$ and decreases when angle exceeds $60^{\circ}$. Also thermal efficiency increases with charge amount of working fluid up to $66 \%$ and decreases after this value. He found optimum condition at $45^{\circ}$ tilt angle and $66 \%$ charge amount of alcohol maximum thermal efficiency were obtained.

Walunj et al reviewed enhancement of heat transfer in heat pipe by using nanofluid. He summarizes the literature on heat pipe with nanofluid. In his work he discussed the effects of filing ratio of nanofluid, volume fractions of nano particles on the heat transfer in different types of heat pipes with various base fluids under different operating conditions. Also he focused on the heat transfer enhancement mechanism with nanofluid, relativity between total heat resistance of heat pipe with nanofluid and existing fluid.

Rudresha et al experimentally investigated thermal performance of closed loop pulsating heat pipe with nanofluid. Also he performed CFD analysis of the experimental results. $\mathrm{He}$ used water based $\mathrm{SiO}_{2}$ nanofluid as a working fluid. He concluded as the 
concentration of nanofluid increases, the heat transfer coefficient increases. His experimental result shows the maximum value of heat transfer rate was obtained at input heat 22 watt with $30 \mathrm{~g} / \mathrm{lit} \mathrm{SiO}_{2}$ nanofluid values $333.33 \mathrm{~W} / \mathrm{m}^{2} \mathrm{~K}$. This value is $27.2 \%$ more than pure water. With increasing in concentration, thermal resistance of heat pipe decreases.

Hanley et al investigated in measurement of specific heat capacity of water based nanofluids. He measured specific heat of nanofluid by following existing two models. First model is based on straight volume weighted average and second model is based on assumptions of thermal equilibrium between particle and surrounding fluid. By using differential scanning calorimeter (DSC), the specific heat capacity of water based nanofluids was measured. He found that the results obtained were excellently agreed with second model and first model predictions deviate significantly from the data.

Zhou et al measured the specific heat capacity (Cp) of water based $\mathrm{Al}_{2} \mathrm{O}_{3}$ nanofluid. $\mathrm{He}$ conducted experiment on differential scanning calorimeter (DSC). His results shows decrease in specific (Cp) of water based $\mathrm{Al}_{2} \mathrm{O}_{3}$ with increase in volume fraction of $\mathrm{Al}_{2} \mathrm{O}_{3}$ with increase in volume fraction of $\mathrm{Al}_{2} \mathrm{O}_{3}$ from $0.0 \%$ to $21.7 \%$. From his graphical results the specific heat of $\mathrm{Al}_{2} \mathrm{O}_{3}$ for $0.1 \%, 0.3 \%$ and $0.5 \%$ concentration is 4.18 $\mathrm{J} / \mathrm{gK}$.

Ferizaj et al studied effect of nanofluid on thermal performance of heat pipe. In his work thermal conductivity of different nanoparticles are given. He discussed on the parameters affecting the thermal conductivity of nanofluid. He also discussed difficulties with production process of nanoparticles and commercialization of nanofluid in heat pipe. Also he suggested future scope for research in nanofluid regarding synthesis, filling ratio, concentration levels and thermo physical properties of nanofluids.

\section{Experimental Set Up}

The below figure 3.1 shows the photographic view of experimental set up. The main components of experimental set up has circular section heat pipe, temperature indicator with thermocouple, tillu motor, heater, voltmeter and ammeter. The specifications of each component have given below.

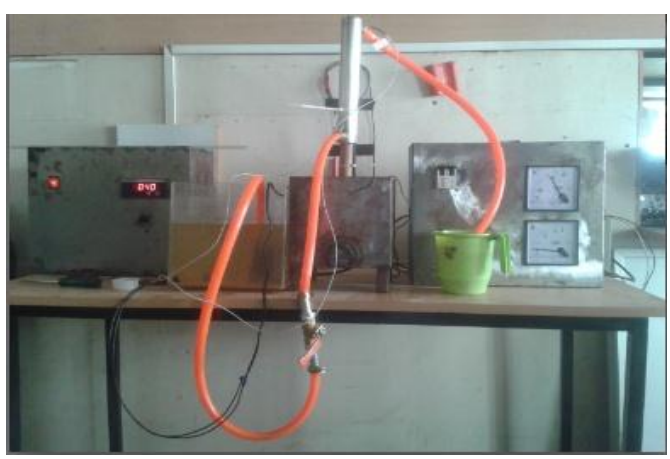

Fig. 3.1 Photographic view of Experimental set up

\section{a) Heat Pipe}

Heat pipe is circular section pipe, which consist of three different regions evaporator section, adiabatic section and condenser section. Evaporator section of heat pipe has placed near hot region and condenser section of heat pipe has been placed near cold region. The function of heat pipe is to transfer heat from hot region to cold region. The specifications of heat pipe are given in table 3.1 .

Table 3.1 Specification of heat pipe

\begin{tabular}{|c|c|}
\hline Length(mm) & 500 \\
\hline Wall thickness $(\mathrm{mm})$ & 0.7 \\
\hline Outer diameter(mm) & $25.4 \mathrm{~mm}$ \\
\hline Inner diameter $(\mathrm{mm})$ & $24 \mathrm{~mm}$ \\
\hline Evaporator length $(\mathrm{mm})$ & $225 \mathrm{~mm}$ \\
\hline Adiabatic length $(\mathrm{mm})$ & $50 \mathrm{~mm}$ \\
\hline Condenser length(mm) & $225 \mathrm{~mm}$ \\
\hline
\end{tabular}

\section{b) Temperature indicator}

The temperature indicator has capable of showing a minimum of 12 different temperatures. Its function has to indicate the temperatures measured at various sections of heat pipe. The thermocouples are used to sense the temperature. Temperature range of thermocouple has $-100^{\circ} \mathrm{C}$ to $+400^{\circ} \mathrm{C}$ and the sheath material is stainless steel grade 304 .

\section{c) Tillu motor}

This motor is placed in reservoir containing cooling water or nanofluid. Its function is to circulate the cooling fluid over the condenser section of heat pipe. Tillu motor operates on 18 watt power and gives maximum discharge $450 \mathrm{~m}^{3} / \mathrm{sec}$.

\section{d) Heater}

Heater is wound over the evaporator section. The input heat is supplied to the evaporator with the help of heater. The maximum capacity of heat generation of heater is 1000 watt.

\section{e) Voltmeter and ammeter}

The input heat is supplied in the form of electricity to the heater. The voltage of input current is measured by voltmeter. The range of voltmeter is $0 \mathrm{~V}$ to $300 \mathrm{~V}$. Magnitude of current is measured with ammeter which has range $0 \mathrm{amp}$. to $10 \mathrm{amp}$.

\section{f) $\mathrm{Al}_{2} \mathrm{O}_{3}$ Nanofluid}

In the present work water based $\mathrm{Al}_{2} \mathrm{O}_{3}$ nanofluid is used with three different concentrations $0.1 \%, 0.3 \%$ 
and $0.5 \%$. Alumina $\left(\mathrm{Al}_{2} \mathrm{O}_{3}\right)$ has very good thermal properties. Alumina $\left(\mathrm{Al}_{2} \mathrm{O}_{3}\right)$ is ceramic material which exhibits several excellent properties. It has very good stability and chemical inertness as compared to metallic nanoparticles ${ }^{[7]}$. The properties of $\mathrm{Al}_{2} \mathrm{O}_{3}$ has given in table 3.2 .

Table 3.2 Properties of Alumina $\left(\mathrm{Al}_{2} \mathrm{O}_{3}\right)$

\begin{tabular}{|c|c|}
\hline Properties & Nanoparticles \\
\hline Molecular Formula & $\mathrm{Al}_{2} \mathrm{O}_{3}$ \\
\hline Melting Point $\left({ }^{\circ} \mathrm{C}\right)$ & 2045 \\
\hline Boiling Point $\left({ }^{\circ} \mathrm{C}\right)$ & 2980 \\
\hline Color & Milky White \\
\hline Density $\left(\mathrm{g} / \mathrm{cm}^{3}\right)$ & $3.5-3.9$ \\
\hline Specific heat $(\mathrm{J} / \mathrm{KgK})$ & 4180 \\
\hline Thermal Conductivity $(\mathrm{W} / \mathrm{m} \mathrm{K})$ & 40 \\
\hline Refractive Index & 1.768 \\
\hline Specific Surface Area $(\mathrm{SSA})\left(\mathrm{m}^{2} / \mathrm{g}\right)$ & 36 \\
\hline Average Particle Size $(\mathrm{nm})$ & $30-40$ \\
\hline
\end{tabular}

\section{Procedure}

The experiment was conducted for four different heat inputs 130 watt, 320 watt, 432 watt and 550 watt. Initially electricity was supplied to heater so that evaporator section of heat pipe gets heated. Five minutes stability period was taken so as system becomes stable. Then DI water was passed over the condenser section of heat pipe. The temperature of inlet and outlet cooling water, surface temperature of evaporator and condenser was measured and recorded with the help of temperature indicator. Then system was reset and restarted and after stability period $0.1 \%$ concentrated $\mathrm{Al}_{2} \mathrm{O}_{3}$ nanofluid circulated over the condenser section of heat pipe and required temperatures were recorded. Similarly $0.3 \%$ and $0.5 \%$ concentrated $\mathrm{Al}_{2} \mathrm{O}_{3}$ nanofluid circulated over condenser section and observations was taken. The same procedure was repeated for rest three heat inputs i.e. 320 watt, 432 watt and 550 watt. During the experiment the mass flow rate of cooling fluid was kept constant and its value was $0.01 \mathrm{Kg} / \mathrm{Sec}$.

The calculations of heat transferred through the condenser section of heat pipe were done with the help of observation taken. The heat transferred to the cooling fluid through condenser section was calculated with the help of formula $\mathrm{Q}_{\text {out }}=\mathrm{mC} \mathrm{p} \Delta \mathrm{T}$. Also the thermal efficiency of the system was found out.

\section{Observation Tables}

The observations were taken during the experiment and they have been recorded in the observation tables. In the observation tables notation $\mathrm{T} 1$ and $\mathrm{T} 2$ indicates cooling water inlet and outlet temperatures. The notation Te and Tc indicates surface temperature of evaporator and condenser section of heat pipe. Table 5.1 shows the reading of 130 watt input heat. Table 5.2 shows the reading of 320 watt input heat. Table 5.3 shows the reading of 432 watt input heat. Table 5.4 shows the reading of 550 watt input heat.
Table 5.1 Readings for 130 watt $\mathrm{i} / \mathrm{p}$ heat

\begin{tabular}{|c|c|c|c|c|c|c|}
\hline \multirow{2}{*}{ Flowing Fluid } & \multicolumn{4}{|c|}{ Temperature $\left({ }^{\circ} \mathrm{C}\right)$} & \multirow[b]{2}{*}{$\begin{array}{c}\begin{array}{c}\text { H.T. to } \\
\text { cooling } \\
\text { fluid(watt) }\end{array} \\
\end{array}$} & \multirow{2}{*}{$\begin{array}{c}\text { Thermal } \\
\text { efficienc } \\
\text { y (\%) }\end{array}$} \\
\hline & T1 & Te & Tc & T2 & & \\
\hline DI Water & 31 & 52 & 49 & 32 & 41.8 & 32.15 \\
\hline $0.1 \%$ Al2O3 & 31 & 53 & 42 & 33 & 83.6 & 64.31 \\
\hline $0.3 \% \mathrm{Al} 2 \mathrm{O} 3$ & 31 & 53 & 38 & 34 & 125.4 & 96.46 \\
\hline $0.5 \%$ Al2O3 & 31 & 54 & 39 & 33 & 83.6 & 64.31 \\
\hline
\end{tabular}

Table 5.2 Readings for 320 watt i/p heat

\begin{tabular}{|c|c|c|c|c|c|c|}
\hline \multirow{2}{*}{$\begin{array}{l}\text { Flowing } \\
\text { Fluid }\end{array}$} & \multicolumn{4}{|c|}{ Temperature $\left({ }^{\circ} \mathrm{C}\right)$} & \multirow{2}{*}{$\begin{array}{c}\text { H.T. to } \\
\text { cooling } \\
\text { fluid(watt) }\end{array}$} & \multirow{2}{*}{$\begin{array}{c}\text { Therma } \\
1 \\
\text { efficien } \\
\text { cy (\%) }\end{array}$} \\
\hline & T1 & Te & $\begin{array}{l}\mathrm{T} \\
\mathrm{c}\end{array}$ & T2 & & \\
\hline DI Water & 31 & 53 & $\begin{array}{l}5 \\
1\end{array}$ & 35 & 167.2 & 52.25 \\
\hline $0.1 \% \mathrm{Al} 203$ & 31 & 55 & $\begin{array}{l}4 \\
5\end{array}$ & 37 & 250.8 & 78.38 \\
\hline $0.3 \% \mathrm{Al} 2 \mathrm{O} 3$ & 31 & 54 & $\begin{array}{l}3 \\
9 \\
\end{array}$ & 38 & 292.6 & 91.44 \\
\hline $0.5 \% \mathrm{Al} 203$ & 31 & 57 & $\begin{array}{l}4 \\
0\end{array}$ & 36 & 209 & 65.31 \\
\hline
\end{tabular}

Table 5.3 Readings for 432 watt i/p heat

\begin{tabular}{|c|c|c|c|c|c|c|}
\hline \multirow{2}{*}{$\begin{array}{l}\text { Flowing } \\
\text { Fluid }\end{array}$} & \multicolumn{4}{|c|}{ Temperature $\left({ }^{\circ} \mathrm{C}\right)$} & \multirow{2}{*}{$\begin{array}{c}\text { H.T. to } \\
\text { cooling } \\
\text { fluid(watt) }\end{array}$} & \multirow{2}{*}{$\begin{array}{c}\text { Therma } \\
\text { efficienc } \\
\text { y }(\%)\end{array}$} \\
\hline & T1 & Te & Tc & T2 & & \\
\hline DI Water & 31 & 54 & 52 & 36 & 209 & 48.38 \\
\hline $0.1 \% \mathrm{Al} 2 \mathrm{O} 3$ & 31 & 58 & 48 & 39 & 334.4 & 77.41 \\
\hline $0.3 \% \mathrm{Al} 2 \mathrm{O} 3$ & 31 & 57 & 40 & 40 & 376.2 & 87.08 \\
\hline $0.5 \%$ Al2O3 & 31 & 59 & 42 & 38 & 292.6 & 67.73 \\
\hline
\end{tabular}

Table 5.4 Readings for 550 watt $\mathrm{i} / \mathrm{p}$ heat

\begin{tabular}{|c|c|c|c|c|c|c|}
\hline \multirow{2}{*}{$\begin{array}{l}\text { Flowing } \\
\text { Fluid }\end{array}$} & \multicolumn{4}{|c|}{ Temperature $\left({ }^{\circ} \mathrm{C}\right)$} & \multirow{2}{*}{$\begin{array}{c}\text { H.T. to } \\
\text { cooling } \\
\text { fluid } \\
\text { (watt) }\end{array}$} & \multirow{2}{*}{$\begin{array}{c}\text { Thermal } \\
\text { efficiency } \\
(\%)\end{array}$} \\
\hline & T1 & Te & Tc & T2 & & \\
\hline DI Water & 31 & 55 & 54 & 38 & 292.6 & 53.20 \\
\hline $0.1 \% \mathrm{Al} 203$ & 31 & 61 & 50 & 41 & 418 & 76.00 \\
\hline $0.3 \% \mathrm{Al} 203$ & 31 & 62 & 44 & 43 & 501.6 & 91.20 \\
\hline $0.5 \% \mathrm{Al} 203$ & 31 & 63 & 45 & 42 & 459.8 & 83.60 \\
\hline
\end{tabular}

\section{Heat Transfer Analysis}

The analysis of heat transfer was done with the help of observations and results obtained. The heat transfer rate increases as the nanofluid was passed through the condenser section of heat pipe for cooling as compared to pure water. As the percent concentration of $\mathrm{Al}_{2} \mathrm{O}_{3}$ nanofluid increases, the heat transfer rate and thermal efficiency of the heat pipe increases. The present work shows maximum heat transfer in the condenser section of heat pipe was obtained at $0.3 \%$ concentration of $\mathrm{Al}_{2} \mathrm{O}_{3}$ nanofluid for all heat inputs. The heat transfer 
rate lowered after $0.3 \%$ concentration of $\mathrm{Al}_{2} \mathrm{O}_{3}$ nanofluid. From these observations it can be noted that the percent concentration of nanofluid can affect the heat transfer rate. For higher percentage of concentration of $\mathrm{Al}_{2} \mathrm{O}_{3}$ nanofluid the properties of nanofluid seems to be in solid phase and it may affect on convective heat transfer rate of the nanofluid.

\section{Results and Discussions}

The observations obtained during the experiment have been used to calculate heat transfer to cooling water. Also the thermal efficiency was found out for different concentrations of $\mathrm{Al}_{2} \mathrm{O}_{3}$ and different heat inputs. The results obtained from calculations have been recorded and these results represented graphically. Fig. 7.1 shows graph between heat transferred to cooling water and different concentrations of $\mathrm{Al}_{2} \mathrm{O}_{3}$. This graph indicates for DI water lowest heat transfer observed for all heat inputs. This is because of water has low thermal conductivity than $\mathrm{Al}_{2} \mathrm{O}_{3}$ nanofluid. The heat transfer rate has been increased for $0.1 \%$ and $0.3 \%$ concentration of $\mathrm{Al}_{2} \mathrm{O}_{3}$, but it has been decreased to some extent for $0.5 \%$ concentration of $\mathrm{Al}_{2} \mathrm{O}_{3}$. This happens because the suspension of nanoparticles in the fluid has significant effect on the enhancement of heat transfer due to higher thermal conductivity, high heat capacity of the nanofluid and higher mixing fluctuations. Hence heat transfer rate increases with increasing concentrations of nanopaticles. However if the nanopaticles concentration exceed $0.3 \%$, the properties of the nanofluid seems to be a solid phase therefore lower evaporation rate of working fluid in the evaporator section of heat pipe. Hence heat transfer rate also decreased.

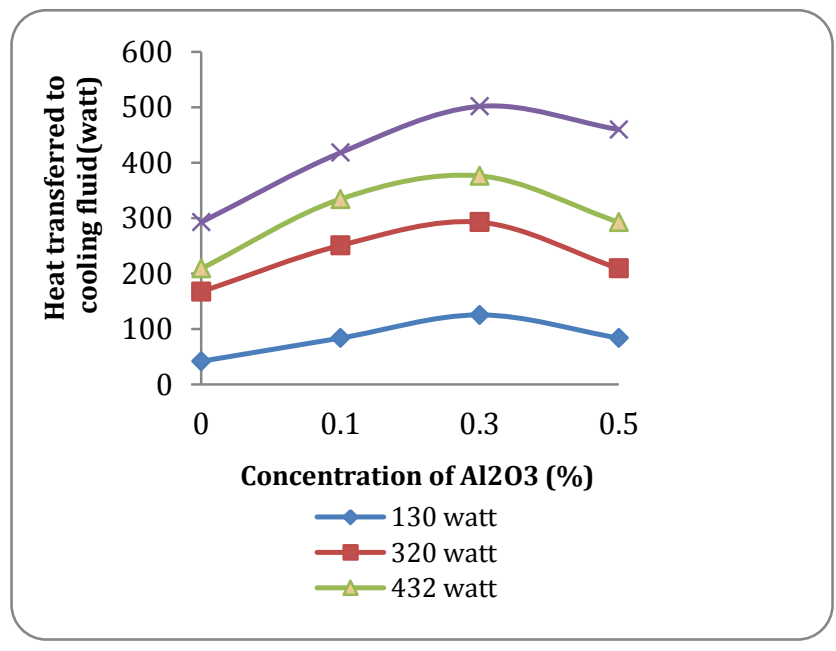

Fig. 7.1 Variation of heat transfer with $\mathrm{Al}_{2} \mathrm{O}_{3}$ concentrations

Fig. 7.2 shows graph between thermal efficiency and different concentrations of $\mathrm{Al}_{2} \mathrm{O}_{3}$. The ratio of heat transferred to the cooling fluid in the condenser section of heat pipe and heat supplies to the evaporator section of heat pipe gives thermal efficiency of the system. The graph shows DI water has obtained lowest thermal efficiency for all heat inputs. From the nature of graph increasing thermal efficiency has been observed for $0.1 \%$ and $0.3 \%$ concentration of $\mathrm{Al}_{2} \mathrm{O}_{3}$. For $0.5 \%$ concentration of $\mathrm{Al}_{2} \mathrm{O}_{3}$, the thermal efficiency lowers but more than DI water.

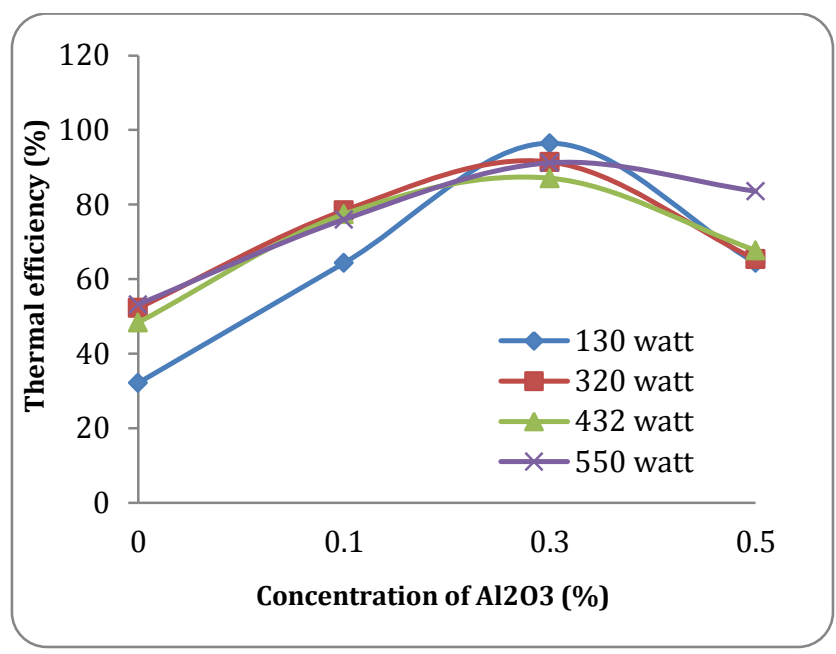

Fig. 7.2 Variation of thermal efficiency with $\mathrm{Al}_{2} \mathrm{O}_{3}$ concentrations

Fig. 7.3 shows graph between evaporator surface temperature and different concentrations of $\mathrm{Al}_{2} \mathrm{O}_{3}$. The nature of graph shows as the heat transfer rate increases the surface temperature of the evaporator section of heat pipe has also increases. For $0.3 \%$ concentration of $\mathrm{Al}_{2} \mathrm{O}_{3}$ maximum heat transfer occurs, at this condition only the surface temperature of evaporator section of heat pipe lowers and remains constant.

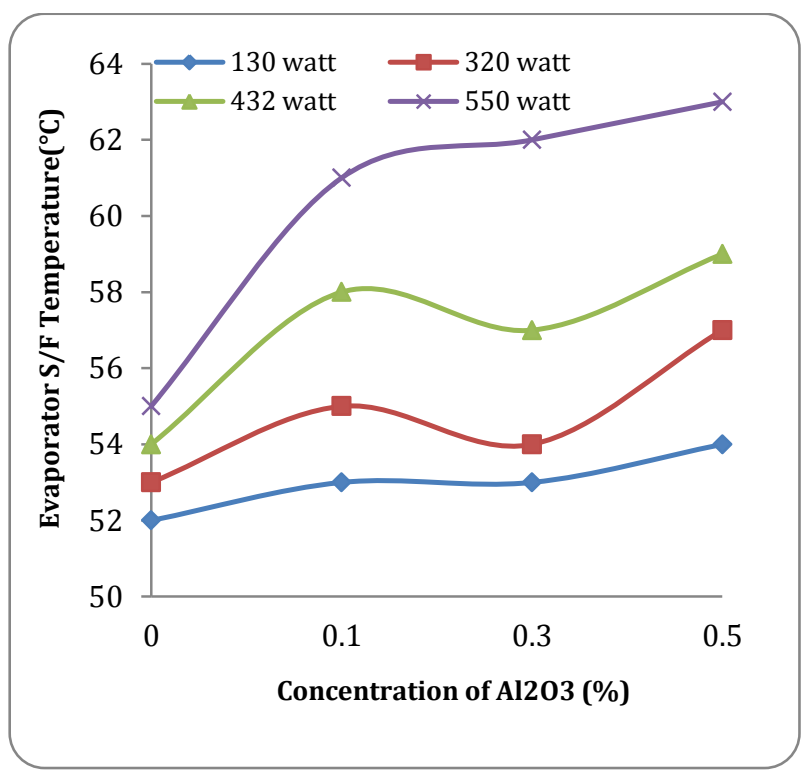

Fig. 7.3 Variation of evaporator surface temperature with $\mathrm{Al}_{2} \mathrm{O}_{3}$ concentrations

Fig. 7.4 shows graph between condenser surface temperature and different concentrations of $\mathrm{Al}_{2} \mathrm{O}_{3}$. For 
DI water maximum condenser surface temperature was observed for all heat inputs. This is because of very low amount of heat has transferred to the cooling water in condenser section of heat pipe. The condenser surface temperature lowers at $0.1 \%$ and $0.3 \%$ concentration of $\mathrm{Al}_{2} \mathrm{O}_{3}$ and it increases for $0.5 \%$ concentration of $\mathrm{Al}_{2} \mathrm{O}_{3}$.

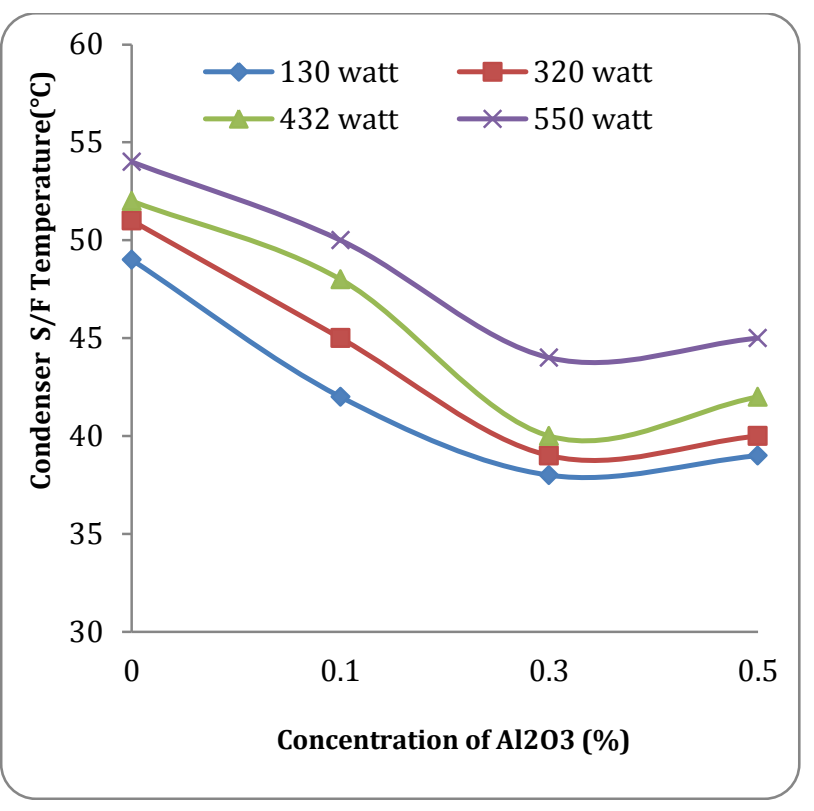

Fig. 7.4 Variation of condenser surface temperature with $\mathrm{Al}_{2} \mathrm{O}_{3}$ concentrations.

\section{Conclusion}

The performance of heat pipe with the use of nanofluid has been investigated in the present work. The enhancement in the heat transfer and thermal efficiency has been observed when nanofluid is used as a working fluid. The nanoparticles play important role in the enhancement of heat transfer in the heat pipe. In the present study following conclusions were made.

- The heat transfer rate increases when water based $\mathrm{Al}_{2} \mathrm{O}_{3}$ nanofluid has used. The maximum heat transfer observed at $0.3 \%$ concentration of $\mathrm{Al}_{2} \mathrm{O}_{3}$.
- The thermal efficiency of the system also increases with the use of nanofluid.

- The evaporative surface temperature increase as the heat transfer rate increases and remains constant for maximum heat transfer.

- From the nature of graph it has been observed that, condenser surface temperature decreases as the heat transfer rate increases.

- The maximum values of measuring parameters were found at $0.3 \%$ concentration of $\mathrm{Al}_{2} \mathrm{O}_{3}$. Hence this concentration may be the optimum.

\section{References}

Paisarn Naphon, (2008), Experimental investigation of titanium nanofluids on the heat pipe thermal efficiency, International Communications in Heat and Mass Transfer, Vol 35, pp 1316-1319

A. Walunj, F.Z. Pathan, A.A. Shaikh, A. K. Hussein, (2015), Heat transfer enhancement in heat pipe using nanofluid - A review, International Journal on Theoretical and Applied Research in Mechanical Engineering, Vol. 4, issue -1, pp 2319-3182.

Rudresha S, Vijee Kumar, (2014), CFD Analysis and Experimental Investigation on Thermal Performance of Closed loop Pulsating Heat pipe using different Nanofluids, International Journal of Advanced Research, Vol. 2, Issue 8, pp 753-760.

Harry 0' Hanley, Jacopo Buongiorno, Thomas McKrell, Lin Wen $\mathrm{Hu}$, (2011), Measurement and model correlation of specific heat capacity of water based nanofluids with Silica, Alumina and Coper oxide nanoparticles, $A S M E$ International Mechanical Engineering Congress and Exposition, Vol. 10, pp 1209 - 1214.

Sheng Qi Zhou, Rui Ni, (2008), Measurement of the specific heat capacity of water based $\mathrm{Al}_{2} \mathrm{O}_{3}$ nanofluid, Applied Physics Letter, Vol. 4, pp 48-53.

Drilon Ferizaj, Mohomad Kassem, (2014), Effect of nanofluid on thermal performance of heat pipe, Bachelor of Science Thesis KTH industrial engineering and management. Vol. 8, pp 23- 57.

Wei Yu, Huaqing Xie, (2012), A review on nanofluid: preparation, Stability mechanism and applications, Hindawi Publiahing Corporation Journal of Nanomaterials, Vol. 18, pp 17. 